\title{
Interest in Foreign Language Learning
}

\author{
Shanty Halim \\ Shantynurul@yahoo.com \\ Politeknik Negeri Ujung Pandang \\ Received : 3 Maret 2019; Accepted : 17 Mei 2019 \\ URL : http://ejournal.iainpalopo.ac.id/index.php/ideas
}

\begin{abstract}
This article describes about the interest in foreign language learning. Interest is a state of wanting to learn or know about curiosity. Interest has a mayor effect towards the learning activity. Interest is a permanent inclination to pay and recall several activities (Djamarah, 2008:48). Interest has a major effect towards the learning activity. Interest is feeling and commitment to something or activity without command. Interest is often regard as being a major element in the teacher's store of motivational tactics (McDonouch, 2013:143). Interest is acceptation to one connection between one self and outside more and more close the connection bigger interest (Slameto, 2008:180). There are six factors that influence learning interest, namely: motivation, attention, attitude, study habit, self concept and student aptitude
\end{abstract}

Keywords: Interest, language learning, influencing factors. 


\section{Introduction}

The significant of teaching process activity as many researchers have study influence by many factors. The factors may occur before or during the process of activity. Some factors come from the students' is needed for the success of their learning. But, when the final result have been exposing, the question should be return to the students themselves. As the teacher and school have given their best effort to develop them, have the students given equals effort in their learning?

Despite of the question above, there are also many factors supporting the success of learning activity. The most important factors, as many theories give are motivation, attention, attitude, study habit, self concept and students aptitude. Interest is a state of wanting to learn or know about curiosity. Interest has a mayor effect towards the learning activity. Interest is a permanent inclination to pay and recall several activities (Djamarah, 2008:48). Interest has a major effect towards the learning activity. Interest is feeling and commitment to something or activity without command. Interest is often regard as being a major element in the teacher's store of motivational tactics (McDonouch, 2013:143). Interest is acceptation to one connection between one self and outside more and more close the connection bigger interest (Slameto, 2008:180).

The students feel English learning is difficult because English learning is different with others. The first is from how to read, how to write, what is the meaning, etc. That is why many students consider English is difficult language. Based on this reason, teachers have to make students interest in learning English. Teachers must have many methods and be creative in teaching English. Li (2011:2) proposed two hypotheses about the important role of the interest in learning process. In a classroom setting, interest is required to meet students' intellectual as well as emotional needs; interest can never be imposed on an individual by external forces, but a teacher can help increase the learners' interest.

Interest is a trend that remains to consider and recalls some activities. Activities that demand was noted continuously that comes with a sense of happy. The taste of pleasure and a sense of interest in the activity without any sent. The interest is basically the acceptance of a relationship between themselves with things or activities outside of themselves. The more powerful or near the relationship is then the greater the interest.

One of the factor that influence in learning is students' interest, because when the lessons not in accordance with the students' interests, the students will not good in learning, because there is no power full for the students. The students are reluctant to study and not get satisfaction from the lesson. Teaching materials have attracted the interest of the students and they will be more easily learn and store.

\section{The Factors that influence Learning Interest}

There are some factors that influence learning interest, namely: motivation, attention, attitude, study habit, self concept and student aptitude.

\section{1) Motivation}

Some psychologist distinguish the term "motivation" and "motive" namely, motive is from motion that means movement or something moving, term "motive" has a close relation 
with "movement", which is done by people. It is also call as action or behavior. In psychology "motive" means stimulus, support and a power riser to do an activity. Fauzi (2009:60) states that the basic definition of motivation is internal situation of organism either human or animal supporting to do something. In this definition, "motivation" means the power source the act directly.

Motivation is the power which motivates somebody to do something suitable her wish, preference organism for to do attitude or behavior that influence by needs and direct with definite purpose before who can plan. The characteristic as control matter for itself. Sudarsono (2006:150) said that motivation is technical term, which is commonly at condition of all operation and motivator, stimulus and motivation. Drever (2008:293) said the motivation is energy change within the person characteristic by affective arousal and anticipatory goal reaction.

Qodratillah (2011:332) states that motivation is encouragement that arises in a person consciously or unconsciously to perform an action with a specific purpose or attempt to cause a person or a particular group of people motivated to do something because they want to achieve the goals she wants or gets satisfaction with actions.

Roekhan, and Nurhadi (2012:11) states that motivation is the extent to which you make choices about (a) goals to pursue and (b) the effort you will devote to that pursuit. Brown (2007:85) said the motivation is change energy in self someone which mark with raises feeling. Motivation is the drive to do something in the meet the needs. Desire of achievement in meeting those needs depends on the motive power. Motive with great power will determine the behavior of individuals. In other words, the motive is the need, the urge, or impulse that determines a person's behavior.

Wahid and Mudjiarto (2006:39) state that motivation is some of internal drive that encourage somebody to pursue a course action. If someone perceive a goal (that is, something we wish to achieve) and if that goal is sufficiently attractive, he/she will be strongly motivate to do whatever is necessary to reach the goal. There are several forms and ways to motivate their learning activities at school, such as giving a figure, gift, rivals or competition, enforcement, knowing the result, praise, punishment, desire to learn, purpose recognize (Sardiman, 2011:92)

There are several kinds of motivation, but here they will only describe from two points of view, the motivation comes from within a person call "intrinsic motivation" and the motivation that comes from outside ourselves that so call "extrinsic motivation".

a) Intrinsic Motivation

The definition of motivation is intrinsic motives that are activate or the functioning does not need to be stimulate from the outside, because inside every individual has no incentive to do something (Fathurrohman and Sutikno, 2007:19).

Based commonly intrinsic motivation is the wish students to take purpose who no external reward. Roekhan and Nurhadi (2012:153) state that intrinsic motivation is motif can function without have to stimulus from external. In addition, Sobur (2013:295) said that intrinsic motivation is motifs that live in students self and useful in function study of condition. While, Sardiman (2011:77) said intrinsic motivation is the motives that become active or not functioning should be stimulated from outside, because in each individual is completed to do something. Meanwhile, Djamarah (2008:35) states that intrinsic motivations are inherent in the 
learning situations and meet pupil need and purposes. Sardiman (2011:77) said intrinsic motivation is motif can function without have to stimulus from external, in own self an individual. There where is motivator itself someone will to do something because he wants to do it.

Intrinsic motivation is intrinsically motivate activities are ones for which there is no apparent reward except the activity itself. People seem to engage in the activities for their own sake and not because they lead to an extrinsic reward. Intrinsically motivate behaviors are aim at bringing about certain internally rewarding consequence, feelings of competence and selfdetermination (Brown 2007:172).

b) Extrinsic Motivation

Extrinsic motivation is the opposite of intrinsic motivation. Extrinsic motivation is the active motifs and functioning due to external stimuli (Djamarah, 2008:37). Extrinsic motivation does not mean that is not necessary and not good in education. Extrinsic motivation necessary for students to learn. Various ways can be done so that students are motivated to learn. Teachers should be able to arouse the interest of students by utilizing the various forms of extrinsic motivation. Misapplication forms of extrinsic motivation will hurt students. As a result, extrinsic motivation not functioning as a driver, but it makes students lazy to study. It has known, that the motivation to give encouragement to a student in the learning activities. For that a teacher should be able to use this extrinsic motivation appropriately and correctly in order to support the process of teaching and learning interactions.

Extrinsic motivation refers to motivation that comes from outside and individual. The motivating factors are external, or outside, rewards such as money or grades. These rewards provide satisfaction and pleasure that the task itself may not provide. An extrinsically motivate person will work on a task even when they have little interest in it because of the anticipated satisfaction they will get from some reward. The rewards can be something as minor as a smiley face to something major like fame or fortune. For example, an extrinsically motivate person who dislikes math may work hard on a math equation because want the reward for completing it. In the case of a student, the reward would be a good grade on an assignment or in the class. Extrinsic motivation does not mean, however, that a person will not get any pleasure from working on or completing a task. it just means that the pleasure they anticipate from some external reward will continue to be a motivator even when the task to be done holds little or no interest. An extrinsically motivate student, for example, may dislike an assignment may find it boring, or may have no interest in the subject, but the possibility of a good grade will be enough to keep the student motivate in order for him or her to put forth the effort to do well on a task. Extrinsic motivation involves doing things to gain outside rewards (Roekhan and Nurhadi, 2012:157).

Extrinsic motivation occurs when we are motivated to perform a behavior or engage in an activity in order to earn a reward or avoid a punishment. Extrinsic motivation is when I am motivated by external factors, as opposed to the internal drivers of intrinsic motivation. Extrinsic motivation drivers me to do things for tangible rewards or pressures, rather than for the fun of it (Sardiman, 2011:79).

Examples of behaviors that are the result of extrinsic motivation include: studying because you want to get a good grade, cleaning your room to avoid being reprimand by your 
parents, participating in a sport in order to win awards, and competing in a contest in order to win a scholarship. In each of these examples, the behavior is motivated by a desire to gain a reward or avoid a negative outcome. Extrinsic motivation is divided into two basic types, integrative and instrumental (Brown, 2007:170).

(1) Integrative Motivation

Integrative motivation is characteristic by the learner's positive attitudes towards the target language group and the desire to integrate into the target language community. Motivation has been identify as the learner's orientation with regard to the goal of learning a second language (Crookes and Schmidt 2006:19). It is thought that students who are most successful when learning a target language are those who like the people that speak the language, admire the culture and have a desire to become familiar with or even integrate into the society in which the language is used (Falk, 2009:17). This form of motivation is known as integrative motivation. When someone becomes a resident in a new community that uses the target language in its social interactions, integrative motivation is a key component in assisting the learner to develop some level of proficiency in the language. It becomes a necessity, in order to operate socially in the community and become one of its members. It is also theory that "integrative motivation typically underlies successful acquisition of a wide range of registers and a native like pronunciation".

In an EFL setting such as Japan it is important to consider the actual meaning of the term "integrative". As Benson (2011:26) suggests, a more appropriate approach to the concept of integrative motivation in the EFL context would be the idea that it presents the desire of the individual to become bilingual, while at the same time becoming bicultural. This occurs through the addition of another language and culture to the learner's own cultural identity. As Japan is predominantly a monoculture society, opportunities to the use target (L2) language in daily verbal exchanges are relatively restrict. There is also limit potential for integrating into the target language community.

(2) Instrumental Motivation

Instrumental motivation underlies the goal to gain some social or economic reward through L2 achievement, thus referring to a more functional reason for language learning. In contrast to integrative motivation is the form of motivation refine to as instrumental motivation. This is generally characteristic by the desire to obtain something practical or concrete from the study of a second language (Hudson, 2010:39). With instrumental motivation the purpose of language acquisition is more utilitarian, such as meeting the requirements for school or university graduation, applying for a job, requesting higher pay based on social status. Instrumental motivation is often characteristic of second language acquisition, where little or no social integration of the learner into a community using the target language takes place, or in some instances is even desire. Learner's with an instrumental motivation want to learn a language because of a practical reason such as getting a salary bonus or getting into college. Many college language learners have a clear instrumental motivation for language. They want to fulfill a college language requirement! Integrative motivate learners want to learn the language so that they can better understand and get to know the people who speak that language. In the North American context, integrative motivation has proven to be a strong impetus to successful language learning. 
Motivation has two components, namely the components inside and outside components. Components in the change in a person is, the state was not satisfied and psychological tension. Beyond components are the needs that wants, goals to be the direction is right. Thus, the components are the needs that want to be satisfy, while the outer parts are goals to be achieve (Hudson, 2010:39).

Motivation is a word that can energize us. Motivation is the key to the achievement of all desires. Motivation is what makes us begin to move, while the commitment is what keeps us going. Motivation can change a person from a state of mediocrity into excellence and extraordinary. The real motivation is what shows up and surged in a person to fulfill all what she expect. Many times we cannot afford to do anything because it did not have sufficient reason to do. So, if we have a desire that steady with a strong motivation to achieve something, then it will lead to what we want. Therefore, if we want to pass the exam $100 \%$ than have the full motivation (super power) or a burning passion to achieve it. This motivation must arise within us. A spirit that is not optimal and giddy. But remember, that was not enough we have the motivation to pass if it is not able to move all the potential to success it, is to perform the action (Benson, 2011:26).

The relationship between the purpose, activities and motivation can be seen from the following figure:

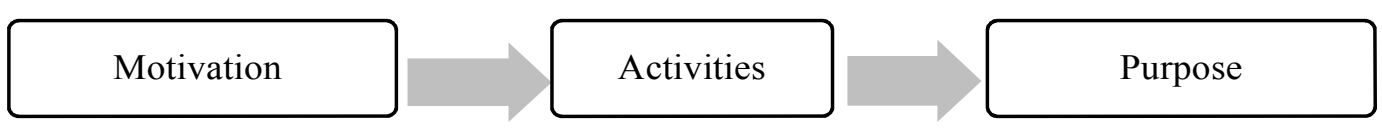

Figure. 1 Relationship between the purpose, activities and motivation

Force that drives individuals calls motivational activities, which indicates a condition within the individual that push or move the individual activities to achieve a goal (Sukmadinata, 2009:61).

Various theories of motivation have been proposed over the course of decades of research, three different perspectives emerge (Benson, 2011:39-42):

a) From a behavioral perspective, motivation is seen in very matter of fact terms it is quite simply the anticipation of reward. Driven to acquire positive reinforcement and driven by previous experience of reward for behavior, we act accordingly to achieve further reinforcement. Skinner, Pavlov and Thorndike put motivation at the center of their theories of human behavior. In a behavioral view, performance in task and motivation to do so is likely to be at the mercy of external forces: parents, teachers, peers, educational requirements, job specifications and so forth.

b) In cognitive terms, motivation places much more emphasis on the individual's decisions, the choices people make as to what experiences or goals they will approach or avoid and the degree of effort they will exert in that respect. Some cognitive psychologists see underlying needs or drives as the compelling force behind our decisions. For example, identified six needs undergirding the construct of motivation: 
(1) The need for exploration, for seeing the other side of the mountain for probing the unknown.

(2) The need for manipulation, for operating to use Skinner's term on the environment and causing change.

(3) The need for activity, for movement and exercise, both physical and mental.

(4) The need for stimulation, the need to be stimulate by the environment, by other people, or by ideas, thoughts and feelings.

(5) The need for knowledge, the need to process and internalize the results of exploration, manipulation, activity and stimulation, to resolve contradictions, to quest for solutions to problems and for self consistent systems of knowledge.

(6) Family, the need for ego enhancement, for the self to be known and to be accept and approve of by others or what calls the self system.

A constructivist view of motivation places even further emphasis on social context as well as individual personal choices. Each person is motivate differently and will therefore act on his or her environment in ways that are unique. But these unique as acts are always carry out within a cultural and social milieu and cannot be completely separated in which ultimate attainment of goals was possible only passing through a hierarchy of needs, three of which were solidly grounded in community, belonging and social status (Benson, 2011:27).

Based on the some theories above, the researcher concludes that motivation is something that can, like self esteem, be global, situational, or task oriented. Learning a foreign language requires some of all three levels of motivation to perform well on, say, the written mode of the language. Motivation is also typically examine in terms of the intrinsic and extrinsic motives of the learner. Those who learn for their own self perceived needs and goals are intrinsically motivated and those who pursue a goal only to receive an external reward from someone else are extrinsically motivated. Finally, studies of motivation in second language acquisition often refer to the distinction between integrative and instrumental orientations of the learner, which we no consider.

\section{2) Attention}

According to Gazali (2010:90), attention is a soul activity which is mode higher the soul is direct to an object or a set of subjects (Slameto, 2008:56). Attention is concentration or our soul activity to ward observation, definition by a putting a side another. Attention means that the concentration of psychic energy is direct to an object lesson or can be said to be much less awareness that accompanies learning activities (Sardiman, 2011:85).

Many times, clinical models different from investigation models, this is the case of attention models. One of the most used models for the evaluation of attention in patients with very different neurologic pathologies is the models of Sohlberg and Matter (Steinberg, 2007:89). This hierarchic model is based in the recovering of attention processes of brain damage patients after coma. Five different kinds of activities of growing difficulty are described in the model, connecting with the activities that patient could do as their recovering process advanced.

a) Focused attention: this is the ability to respond discretely to specific visual, auditory or tactile stimuli.

b) Sustain attention: this refers to the ability to maintain a consistent behavioral response during continuous and repetitive activity. 
c) Selective attention: this level of attention refers to the capacity to maintain a behavioral or cognitive set in the face of distracting or competing stimuli. Therefore it incorporates the nation of "freedom from distractibility".

d) Alternating attention: it refers to the capacity for mental flexibility that allows individuals to shift their focus of attention and move between tasks having different cognitive requirements.

e) Divide attention: this is highest level of attention and refers to the ability to respond simultaneously to multiple tasks or multiple tasks demands.

Attention may be different according to its status 'overt' versus 'overt'. Covert attention is the act of directing sense organs towards a stimulus source. Cover attention is the act of mentally focusing on one of several possible sensory stimuli. Cover attention is thought to be a neural process that enhances the signal from a particular part of the sensory panorama. There are studies that suggest the mechanisms of overt and covert attention may not be as separate as previously believe (Steinberg, 2007:89).

Attention according to Fauzi (2009:66) is mentality process when stimulate or stimulate arrangement conspicuous when the other weak stimulate. We watch is determine by situational and personal factors. Situational factor usually call determiner of external attention or attention getter, stimulate watch because it has dominant characteristics, namely: Action, Stimulus Intensity, Novelty and Reputation.

\section{3) Attitude}

The other factor influence the result of students in learning is attitude. The attitude determines how the individual make reaction to the situation and what the individual looks for in life. Attitude is the dimensionless internal affective symptoms in the form of a tendency to react or respond in a way that is relatively fixed to the object of people, goods and so on, either positively or negatively (Syah, 2013:135). In addition, attitude is a behavior or action which is based on the establishment (opinions, beliefs, etc) or behavior, gestures (Qodratillah, 2011:497).

In special meaning, attitude is the view or mental tendency according to Bruno. Attitude is the relative tendency, settle at to make reaction in good or bad way (Syah, 2013:123). Attitude charge is an idea with emotion that predisposes a class of actions to a particular class of social situations (Slameto, 2008:188). Attitude is potency or ability, if it has developed throw learning, will be a real capability. The students does not have attitude in certain subject will be different in learning it deeply, so that move decrease disposability to get high grade in subject, but in the contrary if the student has attitude so it easy to him learn deeply. Therefore, the possibility to get high is big (Kartono, 2005:2).

Attitude is tendencies that react to make happy or not happy in special stimulate. An attitude always relation to an object and the attitude to this object along with (accompanied) and negative feeling. The people have positive attitude to an object have value in this view, as well as in the contrary. An attitude can be formed trough some ways (Slameto, 2008:108):

a) By frequently experience and along with feeling (traumatic feeling).

b) By imitation, Impersonation can occur unintentionally, may also intentionally. In the last case the individual must have an interest and admiration for fashion, it is also necessary in addition to an understanding and ability to recognize and recall the model to 
be imitation. Imitation will occur more smoothly when done collectively rather than individually.

c) By suggestion, here someone forming an attitude towards the object without a reason and clear thinking, but solely because of the influence that comes from someone or something that has authority in the consideration.

d) By identification, here someone impersonating someone else or an organization/agency based on a certain emotional attachment to nature. Imitate in this respect more in the sense of trying.

The attitudes of students are particularly shape by the personal experiences of schooling and by the specific leaning context (Mckay and Homberger, 2007:18). Thus is cannot be expected that all second language students, whether immigrants of refugees, share similar attitudes toward learning a new language or that native speaker students adding control of a mainstream variant to their native dialects are comparable to second language learners. Attitude toward school instruction in which a community dialect is used and attitude toward school situations in which another language is the medium of instruction, show some contrasts in terms of the pattern of support for bilingualism as an educational goal to be attaining through formal instruction which uses both language forms in the classroom.

It seems unlikely that achievement in foreign languages in British and European schools is affected by integrative motives. Two recent research projects in Britain have investigated the relationship between attitudes and achievement in foreign language. Boy's attitudes to German in a grammar school were investigate in the course of Green's study of language laboratory use at New York. For these boys, liking German was not dependent on whether they had favorable opinions of the people or country. But, as the researchers point out, they had direct experience only of the language. Moreover, there was only weak relationship between achievement and attitudes towards the people of country. It may well be that these pupils regarded German as (just) another school subject rather than something special which was a live language. There is no way of assessing how widespread this configuration of attitudes is (Mckay and Homberger, 2007:18).

A negative attitude toward the target language or its speakers, or the other members of the class could also affect one's determination and persistence to be involve in the class and activities. This same negative attitude could impair memory functions and detract from focusing on the target language. Teachers are generally well aware of this possibility and thus often devise ways to increase positive motivation and attitudes (Steinberg, 2007:177).

4) Study Habit

Indicate the research result various, is study result have positive correlation with study habit. Mappiare (2007:8) defines habit as an acquired way of acting which is persistent, uniform and fairly automatic. Custom actions do not require the attention and concentration of the mind do it. Habits can be walk on, while individuals think about or pay attention to other things. While Bull (2011:199) states that habit is thing that you do often and almost without thinking.

\section{5) Self Concept}

The concept of self is one's view of himself regarding what he knew and felt about his behavior, the thoughts and feelings and how these affect the behavior of others. Here the concept of self in the shadow of one's intent is about the state of his own at this point and not 
the ideal shadow of itself as expect or preferring by the individual concern. Developing selfconcept of one's thoughts about various things about him since he was small, especially with regard to the treatment of others against him (Mappiare, 2007:12).

6) Student Aptitude or Talent

Aptitude is one of man's ability to perform an activity and have around since man was there. It is close to the issue of intelligence is a mental structure that gave birth to "ability" to understand something (Sardiman, 2011:85).

Aptitude as a condition or set of characteristics regard as symptomatic of an individual's ability to acquire with training some (usually specified) knowledge, skill, or set of responses such as the ability to speak a language, to produce music, etc. Aptitude is predictable achievement and can be measure by specially devise test (Sardiman, 2011:85).

In general, potential aptitude is the ability of a person to achieve success in the future. Thus, each person must actually did have aptitude in the sense of potential for achievement to the level specifics in accordance with their respective capacities. So, it is similar to global talent intelligence. That is why a highly intelligent child is very intelligent or smart tremendous also known as a gift child. In a further development, talent then defines as the individual's ability to perform certain task without a lot depends on the education and training efforts.

\section{Conclusions}

The researcher concludes that there are six factors that influence the students' interest in foreign language learning those are motivation, attention, attitude, study habit, self concept, and student aptitude.

\section{REFERENCES}

Abebe, T. T., and Davidson, L. M. 2012. Assessing the Role of Visual Teaching Materials in Teaching English Vocabulary (Report). Language in India, 12(3), 524.

Aduwa-Ogiegbaen, S. E., and Iyamu, E. O. S. 2006. Factors Affecting Quality of English Language Teaching and Learning in Secondary Schools in Nigeria. College Student Journal, 40, 495.

Benson, H. 2011. Principles of Language Learning and Teaching. Fifth Edition. State University. San Francisco.

Brown, D. H. 2007. Teaching by Principles an Interactive Approach to Language Pedagogy. Third Edition. State University. San Francisco:

Brown, H. D. 2007. Principles of Language Learning and Teaching (5th ed.). White Plains, Pearson Longman. New York.

Bull, V. 2011. Oxford Learner's Pocket Dictionary. Fourth Edition. Oxford University Press. New York.

Chen, Y. Z. 2008. An Action Research on Applying Whole-Language Programs to Enhance First- and Second-Graders' Interest in Learning and Reading Comprehension Ability in Chinese Language. Taiwan: National Dong Hwa University, Hualien County.

Chiu, L. H. 2007. Achievement Motivation: Strategies of Theoretical Study and Applications. WINJOIN Book Co. Taiwan. 
Cook, V. 2011. Second Language Learning and Language Teaching (3rd ed.). Arnold. London.

Crookes, M., and Schmidt, H. 2006. The Psychology of Learning and Motivation. Academic Press. New Jersey.

Crow, S. 2009. Interest and Its Contribution as a Mental Resource for Learning. Review of Educational Research, 60, 549-571.

Djamarah, B. S. 2008. Prestasi Belajar dan Kompetensi Guru. Cet. II. Usaha Nasional. Surabaya.

Drever, J. 2008. Kamus Psikologi. Cet. II. Bina Angkasa. Jakarta.

Falk, K. 2009. Self Hypnosis Easy Ways to Hypnotize Your Problems Way. Columbus, Career Press. Ohio.

Fathurrohman, M., and Sutikno, A. 2007. Bimbingan Belajar Mengajar di SMA dan Perguruan Tinggi. Cet. I. Rajawali Pers. Jakarta.

Fauzi, A. 2009. Psikologi Umum. Cet.I. Pustaka Setia. Bandung.

Gazali, M. 2010. Attention to the Foreign Language Learning. Columbus, Career Press. Ohio.

Hudson, 2010. Engaging Students as Learners' (English Teaching Professional). Longman Group. London.

Hurlock, A. 2008. Interest, Learning and Development. Hillsdale, Erlbaum. New Jersey.

Jacobs, G. M., and Hall, S. 2012. Implementing Cooperative Learning. Cambridge University Press. New York.

Kartono, K. 2005. Bimbingan Belajar Mengajar di SMA dan Perguruan Tinggi. Cet. I. Rajawali. Jakarta.

Krapp, A. 2009. The Significance of the Concept of Interest in Educational Psychology. Empirische Paedagogik, 3, 233-255.

Lai, Q. 2010. A Survey of National Taoyuan Senior-High School Students' Interest in Learning Music and Demand for Self-Decision. MA, Taiwan: Department of Music, National Taiwan Normal University.

Li, C. C. 2011. John Dewey's Ethics. Taiwan: Sun Yat-Sen Institute for Social Sciences and Philosophy. Academia Sinica.

Liu, L. 2008. A New Perspective on the Goals of TEFL in China. The internet TESL Journal, IX (11).

Lochana, M., and Deb, G. 2006. Task-based Teaching: Learning English without Tears. Asian EFL Journal, 8(3), 140-164.

Mathew, N. G., and Alidmat, A. O. H. 2013. A Study on the Usefulness od Audio-Visual Aids in EFL Classrooms: Implications for Effective Instruction. International Journal of Higher Education. 2(2), 45-60.

Mappiare, A. 2007. Psikologi Orang Dewasa. Usaha Nasional. Surabaya.

Mayskur, M. 2005. The Interest of Students' Learning Comprehension by Using Language, Laboratory. Unpublished Thesis. Palopo: Faculty of Teacher Training and Education. Cokroaminoto Palopo University.

McDonough, H. S. 2013. Psychology in Foreign Language Teaching. Second Edition, Essex University. Australia.

McKay, L. S., and Hornberger, H. N. 2007. Sociolinguistics and Language Teaching. Cambridge University Press. New York. 
Miles, M. B., and Huberman, A. M. 2014. Qualitative Data Analysis: A Methods Sourcebook. Third Edition. Sage, Los Angeles.

Nasution, S. 2010. Didaktik Asas-asas Mengajar. Cet. II. Bumi Aksara. Jakarta.

Qodratillah, T. M. 2011. Kamus Bahasa Indonesia Untuk Pelajar. Cet. I. Rineka Cipta. Jakarta.

Ramli. 2009. The Factors Influencing the Students' Motivation in Learning English at the tenth grade SMA Negeri 1 Palopo. Unpublished Thesis. Palopo: Faculty of Teacher Training and Education. Cokroaminoto Palopo University.

Richards, J. C. 2011. Approaches and Methods in Language Teaching (2nd ed.). Cambridge, U.K.

Rivers, W. M. 2007. A Practical Guide to the Teaching of English as a Second or Foreign Language. Oxford University Press. New York.

Roekhan, and Nurhadi. 2012. Dimensi-dimensi dalam Belajar ke Dua. Cet. I. Sinar Baru. Bandung.

Sandana, J. 2009. The Students' Interest in Writing Problem Solving at the Second Semester of English Education Study program Cokroaminoto University Palopo. Unpublished Thesis. Palopo: Faculty of Teacher Training and Education. Cokroaminoto Palopo University.

Sardiman. 2011. Interaksi dan Motivasi Belajar Mengajar. Cet. XX. Rajawali Pers. Jakarta.

Schraw, G., and Dennison, R. S. 2014. Assessing Meta Cognitive Awareness. Contemporary Educational Psychology, 19, 460-475.

Slameto. 2008. Belajar dan Faktor-faktor yang Mempengaruhinya. Cet. I. Rineka Cipta. Jakarta.

Steinberg, D. D. 2007. Psycholinguistics. Longman Group. London.

Sudarsono. 2006. Kamus Konseling. Cet. I. Rineka Cipta. Jakarta.

Sukmayanti. 2004. The Influential of Games on Students' Interest in Speaking English of SMPN 1 Larompong. Unpublished Thesis. Palopo: Faculty of Teacher Training and Education. Cokroaminoto Palopo University.

Sukmadinata, S. N. 2009. Landasan Psikologi Proses Pendidikan. Cet. V. Remaja Rosdakarya. Bandung.

Sobur, A. 2013. Psikologi Umum. Cet. I . Pustaka Setia. Bandung.

Syah, M. 2013. Psikologi Belajar. Cet. I. Grafindo Persada. Jakarta.

Wahid, A., and Mudjiarto. 2006. Membangun Karakter dan Kepribadian Kewirausahaan. Cet. I. Graha Ilmu. Jakarta.

Zheng, M., and Zhou, Y. 2014. Influence of English Teachers' Classroom English on Students' Learning Enthusiasm in Junior High School. International Journal of Humanities and Social Science. Vol. 4, No. 6(1). 